\title{
HLA-A*2402-Restricted Multipeptide Vaccine S-488410
}

National Cancer Institute

\section{Source}

National Cancer Institute. HLA-A*2402-Restricted Multipeptide Vaccine S-488410. NCI

Thesaurus. Code C101893.

A cancer vaccine composed of HLA-*2402-restricted epitopic peptides derived from three cancer/testis (CT) antigens, with potential antineoplastic activity. Upon subcutaneous administration, HLA-A 2402 -restricted multipeptide vaccine S-488410 may elicit a cytotoxic T-lymphocyte (CTL) response ag ainst tumor cells expressing these CT antigens. CT antigens, normally expressed only in germ cells of the testis, are overexpressed in a wide variety of human cancers. 